\title{
Oyster feuds: conflicting discourses and outcomes in Point Reyes, California
}

\author{
Haley Leslie-Bole ${ }^{1}$ \\ Eric P. Perramond \\ Colorado College, USA
}

\begin{abstract}
The closure of Drake's Bay Oyster Farm in Point Reyes National Seashore, California, ignited a heated local and national conflict regarding the roles of stewardship and conservation and private business in protected areas. It is vital to examine parks and conservation critically to identify places where they are exacerbating resource struggles that often result from globalization and development, in the United States and in other countries. This article uses Foucauldian discourse analysis to identify conflicting discourses present in this conflict and to analyze knowledge and power in relation to issues of resource and land use in protected areas. This analysis highlights differences in scale and logic between the discourse used by local stakeholders, and the discourse used by conservation organizations and Park officials, in the Point Reyes conflict and in other National Parks.

Key Words: Political ecology, discourse, aquaculture, oysters, Foucault, National Parks, conservation, land stewardship, Point Reyes, protected areas

\section{Résumé}

La fermeture de Drake's Bay Oyster Farm situé près de Point Reyes, Californie, a déclenché un conflit local et national concernant les rôles de l'administration de la conservation et de l'entreprise privée dans les zones protégées. Il est essentiel d'examiner de façon critique la conservation des parcs et d'identifier les endroits où ils exacerbent les luttes pour les ressources qui sont souvent le résultat de la mondialisation et du développement, à la fois aux États-Unis et à l'étranger. Cet article utilise une analyse Foucauldienne sur ses principes du discours pour identifier les contradictions présentes dans ce conflit, et d'analyser la connaissance et le savoir/pouvoir quant aux questions de gestion des ressources et de l'utilisation des terres dans les zones protégées. Cette analyse met en évidence les différences en importance d'échelle et de logique entre le discours tenu par les acteurs locaux et le discours tenu par les organismes de conservation et des agents responsables du parc, tant à la fois dans le conflit de Point Reyes et dans ceux d'autres parcs nationaux.
\end{abstract}

Mots clés: Huîtres, Point Reyes, discours, conservation, parcs nationaux.

\section{Resumen}

El cierre de Drake Bay Oyster Farm en punto Reyes National Seashore, California, encendió un conflicto intenso local y nacional con respecto a las funciones de manejo y conservación de las empresas privadas en áreas protegidas. Es vital examinar parques nacionales y la conservación de forma crítica para identificar los lugares donde están exacerbando luchas de recursos que a menudo resultan de la globalización y el desarrollo en los Estados Unidos y al extranjero. Este trabajo utiliza un análisis de discurso foucaultiano para identificar discursos contradictorios presentes en este conflict, y para mobilizar el concepto del saber/poder en relación con cuestiones de recursos y uso del suelo en áreas protegidas. Este análisis pone de relieve diferencias en escala y lógica del discurso utilizado por los actores locales y el discurso utilizado por las organizaciones conservacionistas y funcionarios del parque federal, tanto como en otros parques nacionales, en el conflicto de Point Reyes.

Palabras clave: Ostras, Point Reyes, el discurso, la conservación de los parques nacionales.

\footnotetext{
${ }^{1}$ Haley Leslie-Bole is a 2015 graduate of the Colorado College (Environmental Anthropology) and now currently affiliated with NatureBridge Yosemite. Dr. Eric Perramond is Associate Professor of Environmental Science \& Southwest Studies at the Colorado College. Email: Eric.Perramond "at" ColoradoCollege.edu.
} 


\section{Introduction}

One sunny afternoon I (first author) sat across from Bill Rivers ${ }^{2}$ at a café in the small town of Petaluma in West Marin County, California. He spoke softly, but with intensity and urgency that conveyed passion and deep frustration. He said:

If you're really concerned about the environment, you need to look at Drake's Bay in the context of what's happening globally right now. Drake's Bay, in my estimation, is probably the quintessential example of sustainable food production. And if we can't honor that, support that, and nurture that in our community, we're toast. Game over. And if people like Sarah Smith and Ben Jones and Cecily Muldoon and Don Neubacher and the rest of these half-witted fools can't see that, god help them. It's unbelievable to me. (Bill Rivers, personal communication)

He sat back in his chair, shaking his head.

Bill is an agroecologist, the director and founder of two prominent local sustainable agriculture nonprofits, and a vocal proponent for Drake's Bay Oyster Company. Bill has spent the past seven years of his life fighting to keep the Oyster Farm in business. The Drake's Bay Oyster Farm has been a fixture on Point Reyes National Seashore (PRNS) for over forty years, but since this article was first written the Oyster farm was forced to shut its doors and vacate the land to enable the creation of the first Marine Wilderness Area on the west coast of the United States.

In this article we examine how the Federal Government, the National Park Service (NPS) and the employees of Point Reyes National Seashore have created a powerful discourse of conservation that has long conflicted with a counter discourse of sustainable local agriculture and working landscapes in the area (see Figure 1). The existence of agriculture and aquaculture within PRNS presents a friction point between these two discourses. This friction culminated in a controversy over the removal of Drake's Bay Oyster Company, and was escalated by a community that has a history of activism and resistance to change. This conflict became a political and legal battle that illuminated differences in power, scale, and ideologies between the participants in the conflicting discourses. We argue that a post-structural analysis of discourses present in this conflict reveals larger difficulties that have made the Drake's Bay Oyster Farm conflict virtually unresolvable and damaging to the community, and there are indications that conflicting discourses are present and problematic in other National Parks in the United States.

These discourses and the conflicts they have created in PRNS have similarities with many national and global conflicts. Robbins' (2012) observes that the

...control of resources and landscapes has been wrested from local producers or producer groups (by class, gender, or ethnicity) through the implementation of effort to preserve 'sustainability', 'community', or 'nature'. In the process, officials and global interests seeking to preserve the 'environment' have disabled local systems of livelihood, production, and sociopolitical organization (Robbins 2012: 178).

Thus, conservation entails elements of a coercive state, and results in the loss of social capital due to erosion of the moral economy (West 2006). A discursive analysis of The Drake's Bay Oyster Farm conflict demonstrates consistency with conservation and control issues, suggesting that the issues plaguing the PRNS share similarities with many other national and global contestations about conservation spaces (Adams and Hutton 2007; Brown 1998; Jamal and Eyre 2003; Kull 2002). Specifically, the oyster farm conflict is one of many other cases in National Parks throughout the country where the NPS faced accusations of mishandling

\footnotetext{
${ }^{2}$ Informant names have been changed to pseudonyms protect their privacy. When the "I" is used, it refers to the lead author (HLB) in her personal interviews with informants.
} 
or misrepresenting scientific data to back the removal of agriculture and private inholdings from Park lands, which we discuss in subsequent sections.

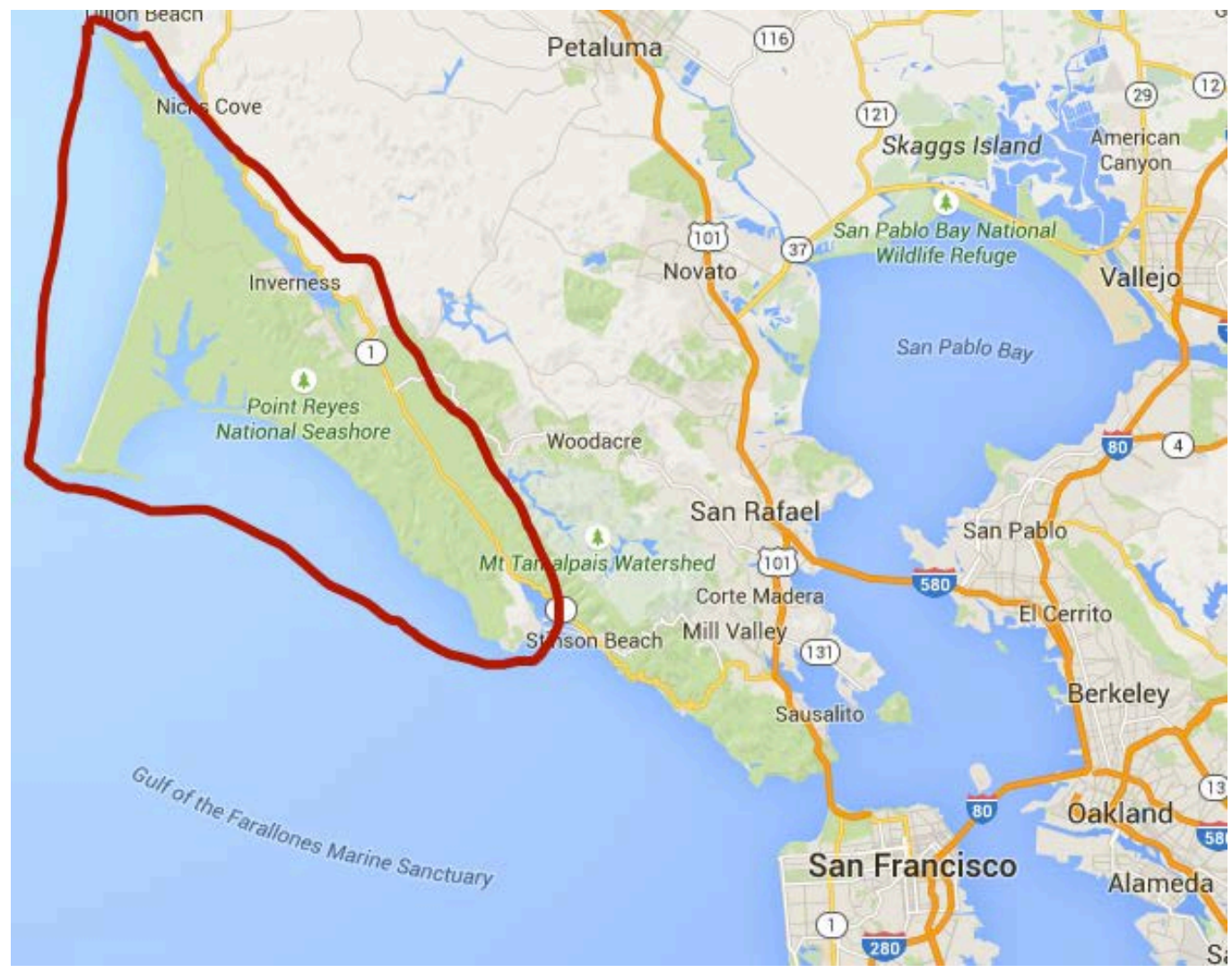

Figure 1: Point Reyes National Seashore, circled in red, is located to the northwest of the San Francisco Bay Area (Map courtesy of Google Maps).

While there is a significant body of political ecology literature on protected areas and conservation in third-world countries (Moore 1993; Neumann 1992; West 2006), this article contributes to the stillinsufficient treatment of parks in developed countries, particularly in the United States. To be sure, there may be more egregious suffering, obvious power discrepancies, and displacement of native or local people in less developed countries, but the complex stakeholder dynamics at play in conservation spaces in the United States deserve more attention. Existing scholars have addressed the displacement of native people in National Parks (e.g., Burnham 2000), and paid increasing attention to non-native locals' ongoing struggles with the NPS that stretch far past the inception of the park or protected area (see also McCoy and Haenn 2013; Schroeder 2005; Walker 2003). Langston and Cronon's book on the complex environmental and political history of Malheur National Wildlife Refuge (2003), Weaver's analysis of poor Appalachian settler exclusion in the creation of the Great Smoky Mountains National Park (1996), and Stern's article on trust between National Parks and neighbors (2008) are other notable works that bring light to these North American backyard political ecologies. This growing body of first world political and ecological literature provides an important perspective on the dynamics inherent in managing protected areas with diverse stakeholders, changing ecological needs, and political priorities.

Protected areas are not static once they are bounded and written into law; they are dynamic and subject to change and conflict as environments change, power dynamics change, and management policy changes. Thus, the PRNS case is important because of these recent protections and use-removals that are in 
flux and that raise important questions about humanity's role in parks and protected areas. In addition, there is a growing counter-literature on the importance of protecting working landscapes that support biodiversity and sustainable human livelihoods to address the problematic erosion of community infrastructure and social capital sometimes present in protected areas (Charnley et al. 2014; IUCN 2014; Phillips 1999; Robbins 2012). This literature, however, focuses on private land and lacks in-depth analyses of working landscapes in or around National Parks and similar protected areas.

West et al. (2006) observed that "The lack of European regions in the literature demonstrates the relative lack of hardship created by protected areas on this continent", but it is difficult to believe that park creation and resource enclosure are entirely unproblematic in Europe (e.g. Vaccaro and Beltran 2009). Heatherington (2010), in another European example, discussed the problems with a potential National Park in Sardinia, and observed that conservation, wherever it occurs, engages problematic narratives about nature and humanity's right or ability to use it sustainably. As the preservation of biodiversity becomes more vital and environmental conflicts more pervasive, parks and protected areas will continue to embody the inherent tensions between environment, resources, and humans.

\section{Political ecology and discourse}

This article engages political ecology to argue that nature and wilderness, as problematic as these terms are, can co-exist with existing local societies and not always be exclusive enterprises. Humans shape their environment and the environment shapes humans, co-creating one another discursively. Humans and nature inform and are being informed by social constructions and political institutions (Escobar 1996, Escobar 1999; Hull et al. 2001; Little 1999; Moran 1990). We espouse a post-structural political ecological perspective to evaluate the relationship between knowledge and power in relation to environmental issues of resource and land use, engaging the Drake's Bay Oyster Farm conflict as a basis for illuminating these dynamics. As Escobar (1996:1) argued, post-structural political ecology is useful because it

... reflects not only the growing belief that nature is socially constructed ...; it takes a step further in insisting that the constructs of political economy and ecology - as specifically modern forms of knowledge - as well as their objects of study must be analyzed discursively. It is necessary to reiterate the connection between the making and evolution of nature and the making and evolution of the discourses and practices through which nature is historically produced and known.

Ideas about nature and the environment are produced and reinforced through discourses, which are creative narratives that explain the world. They come to be unquestioned and accepted as common-sense truths through systems and practices that reinforce them. These systems are always political and produce discourses that align with powerful actors and interests (Robbins 2005: 70, 219).

A 'post-structural political ecology' draws on Foucault's theories of knowledge and power creation through discourse (Escobar 1996). Yet discourse, according to Foucault, is not just a linguistic tool but a meaning-making structure that "governs the way a topic can be meaningfully talked about and reasoned about. It also influences how ideas are put into practice and are used to regulate the conduct of others" (Wetherell, Taylor and Yates 2001). Discourse and the production of truth are inseparably linked to power, in that powerful agents produce discourse which becomes apparent truth. Thus, Foucault (1980) stated:

Truth is a thing of this world: it is produced only by virtue of multiple forms of constraint. And it induces regular effects of power. Each society has its regime of truth, its 'general politics' of truth: that is, the types of discourse which it accepts and makes function as true; the mechanisms and instances which enable one to distinguish true and false statements, the means by which each is sanctioned; the techniques and procedures accorded value in the acquisition of truth; the status of those who are charged with saying what counts as true (Foucault, in Schneck 1987: 22). 
Here, Foucault explains that power, disseminated through politics and social mechanisms, has the capacity to define truth; therefore truth and knowledge are constructed within society. Truth here is not universal or fundamental truth; it is a set of ideas and constructs that are socially produced by power relationships, such as the state or other agents. These kinds of truths can take the form of environmental orthodoxies, or created narratives about the state of nature and humans' relationship to it. Notions of truth, narrative, and discourse are present in the Drake's Bay Oyster Farm conflict, as we discuss below.

Reich (2001: 97) argued that in the case of national parks or national seashores such as PRNS, "Through park rangers, museum displays, maps, brochures, press releases, and wayside signs, every national park creates a narrative to explain itself." This narrative is disseminated to visitors and reinforces the park's mission and actions. The NPS is one of the most well-respected government agencies in the United States, and its rangers carry a reputation of good deeds, heroism, and authority (Berkowitz 2011; Wilson 2014). The NPS therefore has the agency to create influential stories about the landscape that visitors largely accept as truth. These stories, however, sometimes conflict with local knowledge or worse, lived experience that is gained from generations of residence on the land, but is less valued as truth because the narratives are not being disseminated by a respected government agency. A post-structural or Foucaultian approach to understanding NPS-community interactions is important because it allows for a hermeneutical analysis of nature and the narratives that surround it, and an understanding of differential agency and power dynamics between stakeholders.

These discourses as truth are important where nature or conservation is concerned because power, influential social constructions, and environmental orthodoxies influence management policy and science and produce material results (Escobar 1999; Forsyth 2013; Proctor 1998; Robbins 2012). The Park Service's environmental mission and its mission to govern the people and land within Park boundaries produce a powerful discourse that makes existing livelihoods difficult to practice if they do not conform to the park's vision of humans and the environment. Dilsaver and Wyckoff (2005: 237) explain:

A national park is a political entity with a political raison d'être: environmental protection for inspirational recreation. As such, it has bounded territory, a land-use philosophy, and a mission to survive and succeed. It is like a country in that its leaders will fight to maintain territorial integrity, attempt to influence neighbors, and control alien interests within its boundaries.

This is not to say that there is no resistance to the NPS's narratives and actions. Since power is a product of relationships, not a static entity, power is the result of struggles between agents. In Point Reyes and in other parks, local people struggle against the NPS's authority over land and resources. They struggle to make their narratives and realities heard and valued. Where the NPS is the most opaque and secretive in its practices, there is a parallel resistance and struggle from local people. They object to the agency's presumption of privileged knowledge, or a privileged agency discourse. Thus, our presumption here is not simply critique of the NPS and its actions, but rather a cautionary reminder of how local stakeholders perceive and interpret the language, actions, and policies of NPS bodies at work, locally in the Point Reyes region.

While there are as many variations and interpretations as there are stakeholders and community members in the Drake's Bay Oyster Farm conflict, we have identified two main discourses being employed. First, the NPS, which manages Point Reyes National Seashore, operates within a discourse that reflects its powerful status as a governmental agency. Because of its agency mission and scale, the NPS creates policy and makes decisions that adhere to United States law, and tends to undervalue local complexities and local knowledge. The Park values land conservation measures that exclude human use, and it values the concept and designation of Wilderness. Second, many community members and supporters of the Oyster Farm operate within a counter discourse of local, sustainable agricultural systems and working landscapes. This discourse values community connections, local history, and sustainable farming, and is suspicious of federal agency agendas. Burt Belmark, a forty-year Point Reyes Station resident told me: "... there really is a divergence between the federal approach and the local approach. And I think people took that as antagonism" (Burt Belmark, personal communication). In this statement, Burt identifies the two different framing 
discourses at play and recognizes the friction that this consequently creates. These two discourses and their reinforcing social and political structures have co-existed somewhat successfully in the Point Reyes area since the National Seashore was established in 1962, but there have been numerous skirmishes throughout the Park's history that appear to have culminated in the battle over the Drake's Bay Oyster Farm.

\section{Methods}

This study relies on the analysis of interviews conducted during September 2014. The lead author spent a month in the town of Marshall, California, on the mainland side of Tomales Bay, interviewing community members in person and on the phone and attending community events and visiting ranches and oyster farms. The Drake's Bay Oyster Farm conflict was writ large in the local newspapers, the Point Reyes Light and the West Marin Citizen, for several years, and letters to the editor and commentary submitted have closely resembled the opinions gathered from informants on both sides of the conflict. Early in the research period, close friends in the community introduced me to initial informants, which led to new research contacts.

During the research period, the lead author conducted 20 interviews with community members and stakeholders. While this limited sample does not necessarily represent all stakeholders' opinions, it does encompass a range of views that can be taken as representative of the diversity of perspectives in the community. Seventeen of the twenty people interviewed currently live in one of the towns nearby or adjacent to Point Reyes National Seashore, and most have lived in the area for twenty years or more. Three currently or previously worked for non-profit environmental organizations that partnered with the NPS for conservation and restoration work. Three worked for local media, and two had written on the conflict in statewide or national publications. Six informants had been involved in the Drake's Bay Oyster Farm court proceedings in various capacities, on both sides of the conflict. Three worked at the Drake's Bay Oyster Farm, and three currently or previously had ranching or farming operations in the area. Others had followed the conflict closely because of the impact it had on the region and community, and because they were friends with the people involved.

For each discussion, questions were modified according to the person's experience and position within the community, to maximize multiple voices and expression. Open discussions and questions allowed informants to tell stories and add information they felt was appropriate. Each in-person conversation was recorded, with detailed notes for phone interviews, and all were then coded by theme to identify the divergent discourses discussed in this article.

Based on interview transcripts and notes, we identified eight themes used to code the interviews: 1 ) defining the Point Reyes community, 2) community perception of the NPS, 3) the relationship between the Park and ranchers, 4) park and land management history, 5) the Drake's Bay Oyster conflict, including politics and people's perceptions of the conflict, 6) peoples' perceptions of issues underlying the conflict, including ideology and politics, 7) the impact of the conflict on the community, and 8) larger implications of the conflict for Point Reyes and the country. We chose to use discourse analysis to capture the pervasive split between Park voices and community viewpoints reflected in interviews.

\section{Point Reyes history}

The history of Point Reyes is reflective of the long legacy of human use in the area. For thousands of years, Coastal Miwok burned, cleared, and cultivated the coastal land that is now Point Reyes, until Mexicans divided it into land grants in the early 1800s. In 1857 the San Francisco law firm Shafter, Shafter, Park and Heydenfeldt obtained 50,000 acres (20,234 ha) on the Point Reyes Peninsula, and in 1866 divided the land into 33 dairy ranches that were operated and managed by tenant ranchers and many immigrant workers. As Figure 2 shows, many of the ranches were designated by letters of the alphabet, which remain today (Sadin 2007). 


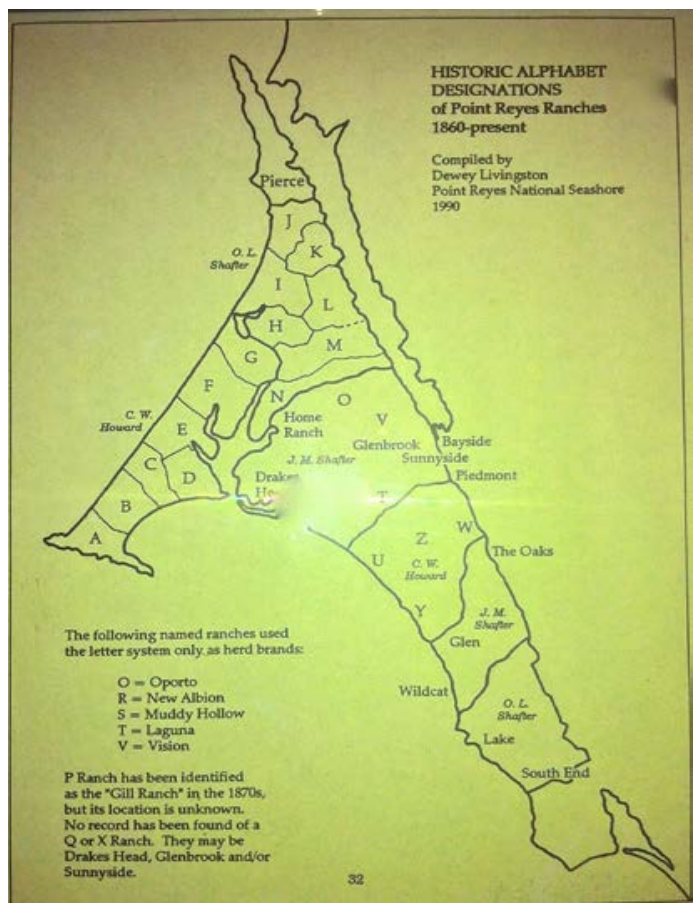

Figure 2: Alphabetic designations for Point Reyes ranches, 1860-1990. (Source: photograph of a map in Point Reyes Meats, author).

While dairying has historically been central to the economy and culture of the Point Reyes area, fishing and aquaculture have also contributed significantly to the area's character. The continental shelf off the coast of California causes an upwelling of deep, cold, nutrient rich water that supports an abundance of marine life near Point Reyes (Evans 2008). This water fills the sheltered Drake's Estero and Tomales Bay, creating ideal conditions for farming oysters. Since the late 1940s when oyster-growing operations in San Francisco Bay failed, people have farmed non-native Olympia oysters in Drake's Estero and Tomales Bay, supplying the city and coastal towns with protein-rich delicacies (Meyer 2011).

\section{Point Reyes National Seashore legislative history}

As early as the 1930s, the Point Reyes area was considered for a National Park designation because of its beauty and biodiversity, but the dairy business was still very profitable on the Point, so there was resistance to a park that would displace the ranches (Watt 2013). During the 1950s, however, dairy farming became less profitable because of increased taxation and large-scale competition elsewhere, and some dairies on Point Reyes were forced to close. The 1960s brought increased interest in conservation, and the preservation of open spaces in the San Francisco Bay Area as suburban development continued to spread, increasing interest in conservation of Point Reyes land. While support for conservation on the Point gained momentum, the question of what to do with the ranches continued to plague the NPS. Many proponents of the seashore believed that the ranches' pastures added aesthetic appeal to the area, but might restrict public access to beaches and hiking areas (Sadin 2007: 46). The NPS sought to compromise with the ranchers and suggested that they would buy the ranchers' land and lease the land back so that ranchers could continue their dairy operations. This idea, however, was met with an outcry from the ranching community. A long-time dairy rancher on the Point is reported to have said: 
We have a large business - a dairy business - out in this area, plus all of our neighboring ranchers out there who also have. We have raised our families out there and our fathers before us. We all have children. We require that property to make a living. We don't want anybody to come over there and take it away from us. (Sadin 2007: 47)

This may have been the first of many conflicts between the NPS operating within a narrative of conservation and human exclusion, and the locally-based and historically-rooted counter-discourse. The final Point Reyes bill included a 'pastoral zone' within the National Seashore that sought to mollify the ranchers and decrease the cost of purchasing land for the Park. The ranchers would be allowed to retain ownership of their lands as long as they did not "upset the pastoral scenic effect of this particular area" (Sadin 2007: 89), in which case the Park would take the land. In the event that the ranchers decided to sell their land, the Park would purchase it and add it to park landholding. Other business would also be allowed to remain, notably the Johnson Oyster Farm in Drake's Estero, which would later become the Drake's Bay Oyster Farm. On September 13, 1962 President Kennedy signed the Point Reyes National Seashore Bill, which acknowledged the economic and scenic importance of the ranching on the Point, and brought Point Reyes National Seashore into existence (Watt 2013).

According to Beth Carey, whose doctoral work has focused on the working landscape in the Point Reyes Area, the PRNS legislation has historically reflected an appreciation for agriculture and aquaculture, and a desire for it to remain on the Point. According to Sadin (2007), however, the Pastoral Zone 'compromise' had nothing to do with an appreciation of the working landscape or of ranching culture, even though legislation has historically supported agriculture:

During debates regarding the authorization of Point Reyes National Seashore, many members of Congress described the ranches either as obstacles to overcome in gaining congressional authorization, or opportunities for obtaining the most territory without incurring an insurmountable price tag (Sadin 2007: 89).

The pastoral zone 'compromise' can be viewed as a governmental act of coercion that ultimately expedited the Seashore's formation and laid the groundwork for power struggle between the NPS and ranchers. In subsequent years, the government has purchased all of the ranching land from Point Reyes dairy, beef, and oyster farmers, and now leases the land back to its tenants in precisely the same way that the ranchers objected to at the Park's inception.

Reviewing the environmental history of Point Reyes, then, suggests that the area's 'natural' landscapes are in fact human-produced and human-altered, and that there has historically been tension between ranchers and the NPS. Next, we turn to the off-shore effects of the PRNS conservation discourse as it changed over time and its long-term consequences.

\section{The Drake's Bay Oyster Farm conflict}

Given PRNS's past, it is unsurprising that Park-community dynamics have been troubled over the years. PRNS was a unique experiment in coexistence between agriculture, recreation, and conservation. Nowhere else in the US does one see private agriculture existing to such a significant extent on National Park Service land, although other places are experimenting with this kind of management. In Cuyahoga Valley National Park in Ohio, the Park Service has restored old homesteads and now leases the land to farmers, but these farms are not managed by families with generations of history on the land, and appear to be more for cultural preservation than actual large-scale production (Cuyhoga Valley National Park 2014). While this experiment in coexistence in Point Reyes was more or less successful depending on who you ask, the National Seashore's history illuminates the roots of frictions between the Park Service's agenda and ideals, along with the interest groups that support their agenda, and the highly local-centric community of ranchers and people living in the towns around the Park. 
Until recently, any conflicts that arose were resolvable. In 2006, however, a conflict of new proportions emerged over a Marine Wilderness Area and the Drake's Bay Oyster Farm. Its enormity seems out of proportion to the size and importance of an oyster farm on a small National Seashore. The best and possibly only way to decipher this conflict and its implications is to analyze the foundational narratives, discourses, and political and social structures that underlie it. It is complex because it is not only a conflict between the Park and the community; it is a conflict between discourses of different scales and ideology, which seem incompatible.

Mary Wheatly used to work for a non-profit partner to the NPS in Point Reyes. She explains:

There's always underlying resentment, and certainly there are huge swathes of the community that just absolutely have demonized the Park Service. And see I know a lot of the community that doesn't feel that way... If it were a united front against the Park Service it would be one thing, but it's not. That's why it's been so hard on the community. It has split the community in two. People walk on the other side of the street; they don't talk to each other in line at the grocery store. It's just crazy (Mary Wheatly, personal communication).

The ruptures in the community concern deeply rooted beliefs about the human relationship to nature, the role of land conservation, and the future of the Point Reyes area in the face of increasing connectivity to the greater San Francisco Bay Area and decreasing reliance and cohesion of local systems. In short, an analysis of the Drake's Bay Oyster Farm conflict highlights a continuing divide between a national and global discourse of conservation by large-scale agencies and organizations, and a regionally-specific discourse that prioritizes local connections including agriculture and the wisdom of long-term residents (Heatherington 2010; Robbins 2012).

As with all complicated matters, not everyone involved falls neatly into one of these two discursive models. It is important to acknowledge that a community is not homogeneous, and that a given individual may be a part of several different communities (Pyburn 2011). In the Point Reyes area, a cross-section of the 'community' may reveal liberal ex-professors, conservative ranchers, first-generation liberal farmers, Park Service employees who live outside the Park, people with vacation homes, immigrant workers, and oldtimers who were born and raised on the shore of Tomales Bay. The Oyster conflict is not a clean split between Park and non-Park, but the conservation discourse is a Park-deployed discourse, and the 'localist' discourse is utilized by non-park community members. Although it may not be possible to fully express the diversity and nuance of opinions in this conflict, it is helpful to use these contrasting ends of the spectrum to understand stakeholders' perspectives and to understand the constructed rationality behind their opinions and actions.

\section{The conflict}

Sarah Smith, executive director of the most vocal anti-oyster nonprofit and a staunch anti-oyster proponent, gestured to a large laminated map of the Point Reyes region tacked to the wall of her office. She pointed to Drake's Estero, a large, many-fingered estuary that extends deep into Point Reyes. "Have you ever kayaked in the Estero?" she asked me.

Hiking around it is one thing, but if you look at the map on my wall, you can see why we kind of call it the ecological heart... But getting out there on the water, there's no question that this is wilderness, it's magical, it really should be preserved. And it really is our only opportunity on the entire West Coast for a Marine Wilderness area. Other estuaries are privatized, commercialized in a way that just wouldn't allow for it. We've known for 36, 38 years, since 1976, when Congress designated it as potential wilderness that this was our only chance. (Sarah Smith, personal communication) 
Drake's Estero is a beautiful, peaceful birder's paradise with Snowy egrets, Great Blue herons, coots, grebes and innumerable other species of raptors and waterfowl. In 1976, Congress designated Drake's Estero as a Potential Marine Wilderness Area, recognizing its wild feel and biological diversity. The only thing preventing the Estero from being an official Marine Wilderness Area was Drake's Bay Oyster Farm perched on the edge of an embayment, farming Olympia oysters in the Estero's waters.

Charles Brown farms oysters in Tomales Bay outside of the National Seashore, and has long collaborated with Drake's Bay Oyster Farm to supply his small restaurant and picnic area where thousands of people come to shuck oysters with their families and enjoy the scenery. His establishment is similar to the former Drake's Bay Oysters. Charles tells me that before Drake's Bay Oyster Farm was shut down, 50,000 people per year visited the Farm's property to eat and purchase oysters. Drake's Bay produced 8 million oysters a year, which represents half of the oysters grown in the state of California, and it was the last oyster cannery in the state. It also was the only facility in California to produce oyster 'seed', or sand-grain-sized baby oysters that it then sold to farms all over the state, including to Tomales Bay Oysters. It is getting harder to make this 'seed' as ocean acidification makes it difficult for oysters to construct their calcium carbonatebased shells. Charles sees the loss of Drake's Bay Oyster Farm as an enormous blow to oyster farming in California, and resents the NPS for the role they played in its elimination.

In 2003, Mark Bishop purchased the oyster farm from Tom Johnson, whose family had owned it since before the National Seashore was created. In 1972, the Johnsons had sold their land to the NPS and were continuing operations on a forty-year lease. The Park did not plan to renew the forty-year lease when it expired, and intended to remove the oyster farm so that Drake's Estero could become the first official Marine Wilderness Area on the west coast of the US. When Mark Bishop purchased the farm from Johnson, he was told that the lease would not be renewed in 2012, but the Bishop family had reason to believe that the Park might be lenient and extend it. The Bishop family has been dairy farming on Point Reyes for three generations, but sold their land to the Park and now operates on 20-year leases that had historically been automatically renewed at the end of every period. ${ }^{3}$ Standing at the now-defunct Drake's Bay Oyster Farm, Carrie Bishop, Mark's sister, showed me two cypress trees visible on the horizon that mark the Bishop Ranch where she grew up and where her family still works. The Bishops hoped the Oyster Farm lease would be renewed, just as it had been on their ranch.

The Bishops also hoped that if they could clean up the Oyster Farm and demonstrate that their operation had no adverse effects on the Estero, the Park might reconsider and allow the Farm to stay. In 2012, however, the Park Service again said that they would not renew the lease, and the Bishops decided to fight this decision. Many influential people took the Oyster Farm's side, including California Senator Diane Feinstein, who attempted to write legislation that would allow Secretary Ken Salazar to renew the lease. This legislation was ultimately useless because Salazar already had the power to renew the lease, and still chose to let it expire in favor of creating a Marine Wilderness Area (Salazar 2012). Each time Drake's Bay Oyster Farm and its supporters went to court to appeal the lease termination; they lost, and they were unable to get their case heard by the Supreme Court.

What might appear to be a fairly simple legal matter of lease renewal was hugely complicated by events beginning in 2006, long before the lease was set to expire. Dr. Alan Goldstein recalls that the theneditor of the local newspaper The Point Reyes Light called him one day and told him "The Park Service is claiming that the oyster farm is doing bad stuff" -- apparently the Oyster Farm was having adverse effects on the Estero's ecology and was polluting the land and water. The editor had just unearthed some studies that ran counter to the claims that the NPS was making, and asked Alan to take a look. After reading these initial papers, Alan did more research and uncovered what he believes to be blatant fabrication of data on the part of the Park Service. He explains that in an effort to justify their decision to terminate the Oyster Farm's lease, the NPS made claims that the Oyster Farm was disturbing Harbor seals (Phoca vitulina) in the Estero and was killing eel grass beds that provide homes for baby fish. According to Alan, both of these claims are based on data that was knowingly collected in dishonest ways or was manipulated to draw false conclusions. Upon

\footnotetext{
${ }^{3}$ Several people we spoke with in 2014 alleged that currently the ranchers were operating on six-month extensions of their leases, while the Park Service constructs a new General Management Plan. Some ranchers worry that their leases will ultimately be terminated, just as the Drake's Bay Oyster Farm's lease was in 2015.
} 
discovering this alleged fraud, Alan wrote a letter to John Holdren, then-science advisor to the President requesting an investigation of scientific misconduct (Goodman 2013). The government has never responded to Alan's request, which to Alan is an indication of their desire to conceal unsavory scientific goings-on.

Science is often used for political leverage, "gathering agency and moral authority over the landscape into the expert hands of institutions" (Heatherington 2010: 70). Federally designated parks are particularly likely to use science to gain power and impose an institutionalized narrative of nature and history on local landscapes, and "...because they are predicated on fictions of wilderness, National Parks enable ecological science and modern bureaucracy to mediate experiences of authentic nature that substantiate official narratives of history" (Heatherington 2010: 142). In this conflict, the NPS tried to wield science as a tool of political power, which incensed community members, and personally offended people who believe strongly in unbiased science. Nathan Bird, a resident of the area, explained to me that the question of fraud drew him into the conflict:

I'm regarded in the community as someone who is on the oyster farm side of the issue, and I am, not because I want the Park Service to extend the lease on the oyster farm but because in the very early part of the struggle, the anti-oyster farm people used fraudulent and misappropriate science to make their case. I used to teach science at UC Berkeley, and to me that's almost a sin to abuse science. To deliberately use fraudulent and scientific misconduct to affect public policy. It's sin. I just really, really dove in against the people who were abusing science to make their point (Nathan Bird, personal communication).

Nathan and Alan were not alone in feeling incensed by the use of perceived "fraudulent" science. Bill Rivers, the agroecologist whom I described earlier in the article stated his feelings unequivocally:

And all that science turned out to be bullshit. Complete bullshit. And Alan Goldstein's work, which you've probably seen... is a stunning rebuke of the fraud, I mean literal fraud. I would stand up in a court of law and say 'Fraud, your honor. Yes, absolute fraud.' Unbelievable...These aren't people who have an ideological commitment to wilderness, that are based on any argument or anything. They are going to lie, cheat, and steal their way to success. And we thought, we hoped, that if the truth were made clear, we would prevail. And of course, we haven't (Bill Rivers, personal communication).

According to Alan, Nathan, Bill, and many others the NPS has an agenda larger than the Oyster Farm. The NPS may be trying to get rid of agriculture on the Point entirely in order to turn the National Seashore into a National Park. Alan, Nathan, Bill and others believe the Oyster Farm is the first privately held agricultural (or aquacultural) business to go, and the rest will follow, as the NPS is able to prove that the ranches are damaging Point Reyes ecosystems and polluting the water.

The Park Service and most anti-Oyster Farm people assert that the Park had no intention of misrepresenting any data, and that there is no hidden agenda to remove the ranches, even if there may have been a slight skewing of the data. Bonnie St. Jean, a former state environmental toxicologist represents the neutral position in the conflict well:

Do I think the Park is a bunch of conniving Nazis trying to take over the world? No. Do I think that the scientists were told to skew some of their results? Of course they were. I work for the state and have been told to skew results one way or the other. It happens. It's not pretty. (Bonnie St. Jean, personal communication)

While defining the truth is important in this conflict, it is unlikely that the opposing sides will ever reach an agreement about what the truth actually is. Ultimately, oysters, eelgrass, and harbor seals are superficial in this issue. What is more important is uncovering the roots of the divergence between pro-oyster 
groups and anti-oyster groups, because this may help community healing and make the inevitable future conflicts easier to resolve.

\section{Conflicting discourses}

An overview of the history of PRNS and the Drake's Bay Oyster Farm conflict reveals that there are two separate discourses being utilized to justify actions and policy. The first, which I will call the 'Conservation Discourse', is systemically embedded in the NPS and in many aspects of American narratives about conservation, nature and land use. This large-scale national discourse influences the policy that creates National Parks and Wilderness Areas, which disseminate conservation ideals to visitors (Heatherington 2010). The National Park system often has conservation science on its side, which it employs as 'truth' and uses this truth to make conservation decisions. This larger discourse manifests at PRNS through the Park employees and Park actions as well as through partner non-profits.

The second discourse, which I will call the 'Local Discourse', is a discourse of resistance to bureaucratic governmental structures and homogenized approaches to environmental management. It counters the Conservation Discourse by valuing human-nature coexistence over formal conservation and human exclusion, and it resists large-scale, generic conservation or Park creation by focusing on local systems and community members. It also posits that farmers are essential environmental stewards, rather than destructive land users. While it is locally oriented, it is also a part of a growing movement towards bioregionalism, local sustainable agriculture, and place-based solutions to environmental problems.

Figure 3 displays one distribution of informants' opinions about whether the oyster farm should remain or be removed, plotted against the scale employed in arguing for or against the oyster farm. It demonstrates graphically the scalar split between pro- and anti- oyster farm stakeholders, demonstrating a key divergence between the two discourses we analyze in this article. For each informant, we assigned a number to the vehemence of their opinion about the Drake's Bay Oyster Farm's right to remain in the National Seashore, 5 being public, active opposition to the oyster farm, and -5 being public, active support for the oyster farm. Zero represents a stated intention of neutrality, and an in-depth grasp of both sides' perspectives. We also assigned a number to our perception of the scale of informants' arguments for or against the oyster farm, 5 being a national orientation, and considering federal laws and legislation including Wilderness designation above all local concerns. A -5 denotes an argument based on local community needs, including the preservation of social capital and consideration of historic land use in the area. Zero represents an understanding and involvement in national politics, and an understanding of the importance of local needs and specificities. The Figure demonstrates that local-centric reasoning is correlated with a pro-oyster farm stance, and national-scale reasoning is correlated with the desire to remove the oyster farm. While this analysis does not capture the nuance present in each stakeholder's opinion and perspective, it demonstrates that there are divergent systems of valuation and scales of reasoning between the two sides of the conflict, pointing to separate discourses being employed. In this section, we will analyze the ways that scale, law/government and nature/wilderness, are conceived and reinforced in both the Conservation Discourse and the Local Discourse, and how these factors affect the Drake's Bay Oyster conflict and other issues on Point Reyes.

\section{The Conservation discourse}

While the NPS is the dominant creator and perpetuator of the Conservation discourse, it is important to note that the NPS is not the only participant in this discourse in Point Reyes. There are several local conservation groups and numerous community members who are interesting in seeing Drake's Estero become a Wilderness Area. This complicates the Conservation Discourse because different stakeholders employ it on a variety of scales.

One primary difference between the NPS and non-Park Service community members is the scale on which they operate and reason. The NPS operates on a national scale, according to national laws. Each Park, Seashore, or Wilderness is a node in the dendritic array of federally conserved land in the United States, 
which must be managed consistently from place to place. The structure of the Park Service also restricts local familiarity in favor of career advancement, according to Mary Wheatly:

... they just move people around as they climb up the ladder, so you have experience in various Parks... you're seen as less tied to a particular park and more to the service. So it's very rare that you see people stay in a particular park for very long. So someone who might start to have a real understanding of, and build those relationships, and build the trust, and build the communication, tend to just be moved on.

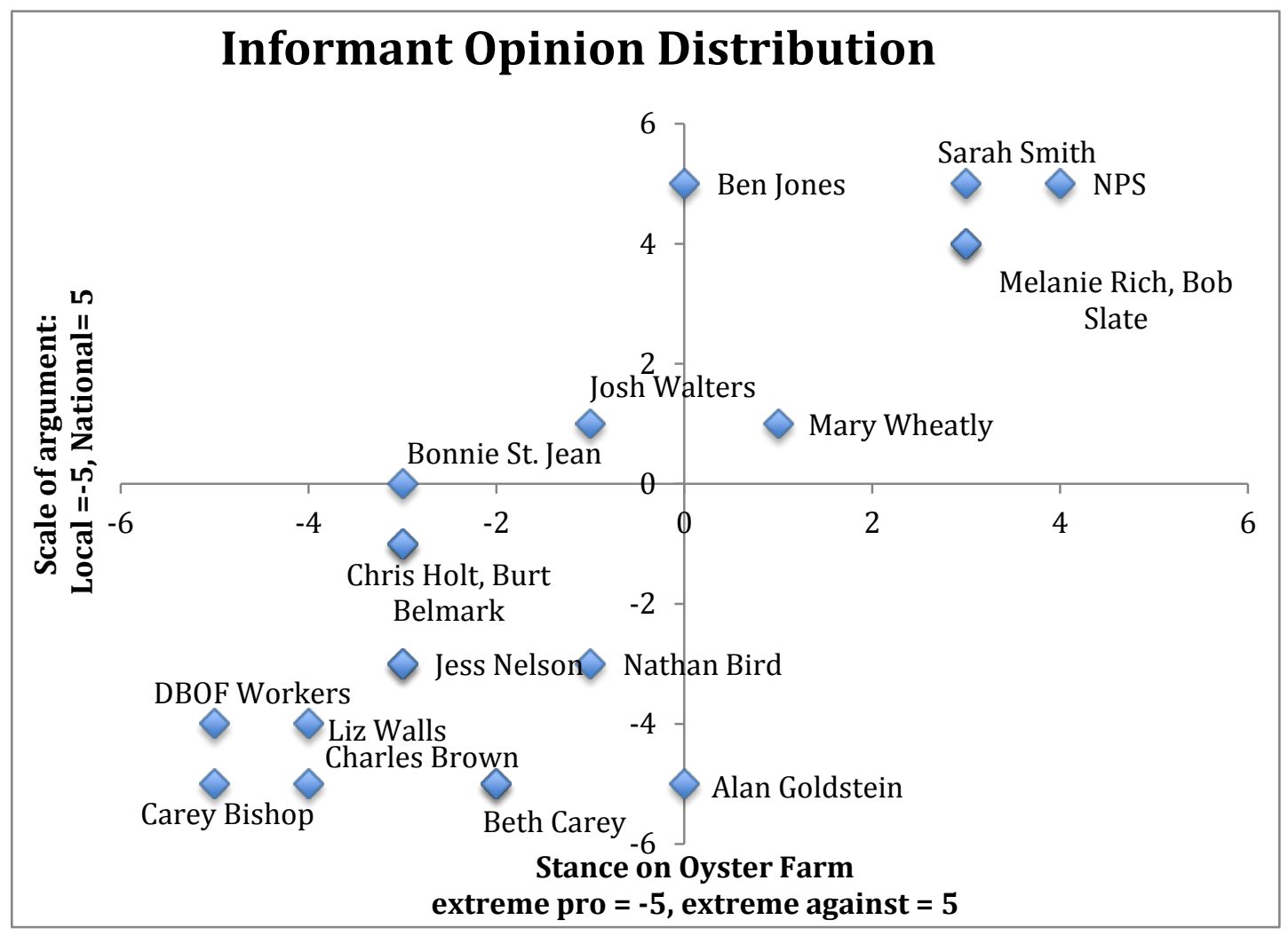

Figure 3: Distribution of informants' opinions based on scale of argument (local level to national level) and their opinion about the Drake's Bay Oyster Farm (staunchly pro-oyster farm to staunchly against). Illustrates differences in scale of reasoning between pro and anti DBOF stakeholders, and the roots of divergent discourses. Source: illustration done by Leslie-Bole.

To advance one's career in the Park Service, employees often move from park to park, and sometimes have limited knowledge of, and concern for local issues (Berkowitz 2011). Because employees are operating on a large, national organizational scale, an understanding of local perspectives may be undervalued, which is definitive of the Conservation Discourse. The Conservation Discourse is not ignorant of specific places, but place fits into the structure of federal conservation, which transcends place. In this case, The Oyster Farm had to be closed because the lease had clearly expired, and by law the land would become Wilderness, and local complications, while unfortunate, could not factor into legal decisions. ${ }^{4}$

\footnotetext{
${ }^{4}$ Some see the Secretary of the Interior's decision not to renew the lease as law-driven and insensitive to the local community as a result of large-scale reasoning. Others, however, believe that renewing the lease would have set a
} 
The National Park Service is not the only stakeholder employing the Conservation Discourse. Even though small, non-profit environmental organizations may not align with some of the Park's practices, we believe they are still operating within the same discursive structure. Formal land conservation currently depends entirely on federal designation: designating Wilderness depends on governmental willingness to do so. In this way, the NPS exercises its power of discourse creation and agency in meeting their goals and conservation agendas. The nearby environmental organizations are compelled to align with the Park to accomplish their conservation goals, and as they promote conservation, they perpetuate a conservation narrative that advocates for human exclusion and further land and off-shore conservation. The president of one of the most prominent anti-oyster groups expressed frustration at being constantly lumped with the Park Service, however. He says that his organization and the NPS may have similar conservation goals, but the Park is "ultimately a large bureaucratic organization...sometimes you see the Park doing something wrong but you can't stop them because they have national interests" (Ben Jones, personal communication). This demonstrates that there is a gradient of power within this discourse, the park being its most powerful architect, followed by environmental non-governmental organizations (ENGOs) that are locally powerful but answer to the NPS. Despite his reservations about working with the Park, Ben Jones's organization is still helping to disseminate Park ideology and practices.

One of the Conservation Discourse's predications is that it speaks on behalf of the American people, and their desires to see their federal land used in a certain way. This deemphasizes the views of local people in proximity to the Park. In August 2014, the NPS released a draft Environmental Impact Statement (EIS) for the Drake's Estero for public commentary. According to Sarah Smith, "We had over 52,000 comments on the draft EIS, and that's one of the highest in Park Service history. 92\% of those said Wilderness. I mean, it was a very clear mandate. The public undeniably was like 'this is ours and we want it preserved"' (Sarah Smith, personal communication). It seems, however, that this conclusion may not have been as unequivocal as it was purported to be. According to Alan Goldstein, and my own observations from reading the draft EIS comments, the vast majority of anti-oyster farm comments were from form letters distributed by the Sierra Club and the National Wildlife Federation, and almost none of the mass mailing commentary had any reference to the actual EIS document (Alan Goldstein, email correspondence). Figure 4 displays Dr. Goldstein's breakdown, depicting the lack of local commentary, or independently generated commentary.

While objectively there may have been a majority of commenters advocating for the removal of Drake's Bay Oyster farm, the assertion that 'the public' had definitively spoken ignores the fact that people often submit form letters not because they know anything about the cause, but because they support the initiatives of the organization disseminating the mailings. Therefore, the views displayed here may not actually be the public speaking, but large ENGOs which align with the NPS, speaking through the mouthpiece of the public. This incensed locally-oriented pro-oyster farm people because the NPS and EAC claimed overwhelming support for wilderness, while ignoring the fact that almost every comment from Point Reyes residents was in support of the oyster farm remaining. This again indicates the Park's macro-scale, national orientation and its assumption that it speaks for the "American people" as if the people were a single and homogeneous body. The Park, because it is government-affiliated, has the final ability to interpret the comments on the draft EIS, and use it to support the creation of a new Marine Wilderness Area.

The draft EIS commentary dispute points to one of the fundamental differences between the Conservation Discourse and the Local Discourse, namely the perception of the validity of wilderness as a concept and institution. Sarah Smith of the EAC told me:

It's pretty crazy, actually... Many of the Oyster Company supporters were like oh, it's not wilderness. The Wilderness Act is antiquated, and they're trying to re-write laws and policies. And we're like... I mean first of all it's nonsensical. You clearly don't understand what

precedent for private business to have sway over federal land management, and this would have opened the door for oil and gas companies to exploit protected lands. 
wilderness is. It is a management standard, and it says no commercialized activities, and it's basically a place where man [sic] is supposed to be a visitor and leave only footprints.

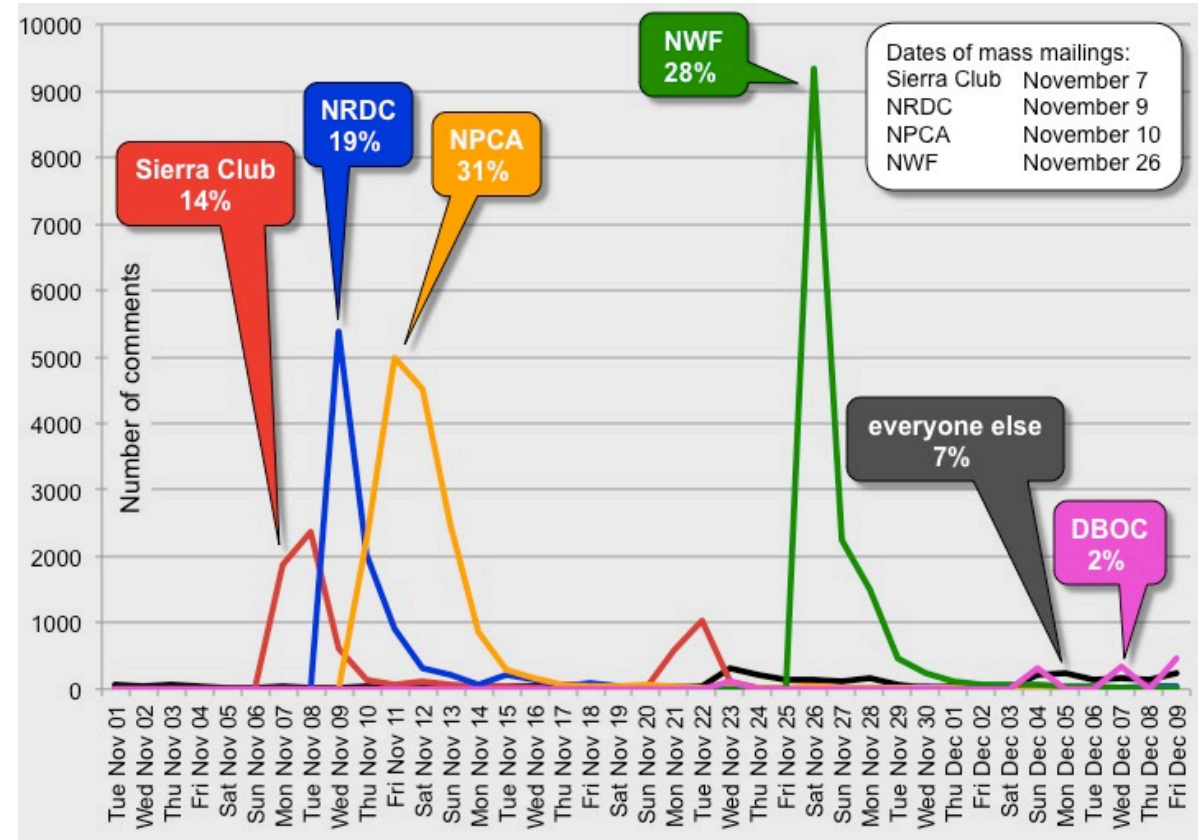

Figure 4: The distribution of commentary on the draft EIS for Drake's Estero. Indicates mass submissions of form letters from the Sierra Club, National Resource Defense Council (NRDC), National Parks Conservation Association (NPCA), National Wildlife Federation (NWF), Drake's Bay Oyster Farm (DBOF) form letters, and 'everyone else', being non-form letter submissions. Source: graph courtesy of Dr. Alan Goldstein, email correspondence, used with permission).

In the Conservation Discourse, the concept and federal designation of Wilderness are closely related. The Wilderness Act defines wilderness as follows:

A wilderness, in contrast with those areas where man and his own works dominate the landscape, is hereby recognized as an area where the earth and its community of life are untrammeled by man, where man himself is a visitor who does not remain. An area of wilderness is further defined to mean in this Act an area of undeveloped Federal land retaining its primeval character and influence, without permanent improvements or human habitation, which is protected and managed so as to preserve its natural conditions and which generally appears to have been affected primarily by the forces of nature, with the imprint of man's work substantially unnoticeable (Wilderness Act 1964).

Given this definition, Drake's Estero is not fully wilderness, both as a designation and a concept, until the Oyster Farm is gone because the Oyster Farm is human intrusion on an otherwise pristine natural place. Business is incompatible with wilderness in the Conservation Discourse, especially a business where people live and create permanent structures like the Oyster Farm. The area's long history of agricultural use is inconsequential; only present biodiversity and scenery is valued as a marker of Wilderness character. This 
concept of wilderness and human relationship to the land is highly problematic to those opposing the designation of a Marine Wilderness Area, which we discuss in the next section.

While the Park is not the only stakeholder employing the Conservation Discourse, the culture and structure of the NPS is fundamental to its creation and reinforcement. Many people identified a culture within the NPS that creates a self-validating, homogenized institutional narrative (Robbins 2012, Beth Carey, Mary Wheatly, Nathan Bird). People were frustrated that the Park Service employees appeared to have a packaged, institutionally approved set of answers to questions, but this makes sense within the Park Service's structure. There has to be institutional consistency to uphold the laws, policies, and ideals that are the bones of the Park Service, which must operate at a national scale. Mary Wheatly has worked closely with the NPS on several long-term projects, and has experienced the frustration of collaborating with an agency that reasons on a large scale, and points to the resulting difficulties in communication:

These are people who have always had a job with the federal government and they got trained... and these people just cannot fundamentally understand what it's like to be a rancher, or fundamentally cannot understand what it's like to be this tiny little organization over here that has completely different realities than they have...So, how do you get people involved to translate in a way that the Park Service can hear? Or on the other side, in a way that the ranchers can hear? (Mary Wheatly, personal communication).

This difficulty in translation or communication is central to the Drake's Bay Oyster Farm conflict. Jess Nelson, editor of one of the main local newspapers, told us that the Park has been extremely uncommunicative to the media, which has led to unintentionally biased journalism. It was difficult to speak directly with NPS employees, which may have resulted in an underrepresentation of the NPS perspective in this article. Because the NPS has been reticent to communicate, the EAC and Sarah Smith have been the selfappointed mouthpieces for the Park. Sarah is forceful, smart, and committed to her cause, but her editorials and articles use inflammatory language, and she is not afraid to make enemies. This may have increased the rift between pro- and anti- oyster contingents. We have observed that the Park's perceived silence and opacity create an unfortunate void that has been filled with conspiracy theories and mistrust. As a result, fear and irrationality have largely driven this conflict, and solidified the divergence between pro- and anti-oyster farm community members (Bill Rivers, Mary Wheatly, Burt Belmark, personal communications).

\section{Local Discourses}

The communities in the Point Reyes area have long been culturally isolated from the larger San Francisco Bay Area because they are rural and culturally resistant to change. What some community members may not acknowledge is that the National Seashore was instrumental in keeping the land open and free of development, and may be the reason that agriculture still exists as it does in the area, but it also is one of the forces that is gradually re-shaping the community (Mary Wheatly, Beth Carey, personal communications). It raised property values, making it impossible for some residents to stay in the area. Oldtimers are being replaced by people who spend a few weekends per year in their vacation homes on the shores of Tomales Bay. Mary Wheatly identifies the complexities of being a "gateway" town to a National Seashore:

This whole area would be completely different if the park had never been created. It would all be development. Even if some of it had gotten saved, there wouldn't be the hiking trails, the access to the beaches. And Point Reyes Station as a town, it's still a ranching community, it's a gateway to the park, they can have all the galleries and those kind of things... I mean people have a vacation home out here because they can go hiking in the park. (Mary Wheatly, personal communication) 
While the Park may have preserved some of the agricultural character of the area and prevented development, the community is undeniably different than it used to be. Liz Walls, age 71 in 2014, grew up in the area and attended a one-room schoolhouse in Point Reyes Station. She remembers a time when there was a very "unique, integrated community", but slowly ranches and homes were sold, and the community lost its social capital. Robbins (2012: 179) defines social capital as "the relationships of trust and expectation between community members built through the investment of time and face-to-face interaction over long periods, invested in traditional management systems stabilizing and regulating ecosystem flows and access to resources." Point Reyes has long been an agricultural area, and according to ranchers and farmers, the agriculture has been an important factor in the health of the landscape and the community. Liz Walls tells me: "Ranches are not a singular effort. It has to be part of a whole community. When one ranch closes down it takes one more cog out of the machine." It is this sentiment of the value of community cohesion and sustainability that largely drives the Local Discourse. A significant part of the pro-Oyster Farm community is not primarily opposing wilderness or even the NPS, although superficially this may appear to be the case. They are opposing a dilution of social capital in their community, and the erosion of traditional land management and economy. Bill Rivers has seen an unraveling of traditional economy and resource use in the area:

But as the ag commissioner in Marin has pointed out many times, that's $20 \%$ of the county's ag (if the ranches on Point Reyes were removed), so as you whittle that away, you begin to undermine all the supporting infrastructure. You break down the supporting infrastructure around agriculture and eventually you destroy the capacity of the region to do that. (Bill Rivers, personal communication)

In Point Reyes, these "supporting infrastructures" include local slaughterhouses and community markets that sell farmstead cheeses, both of which keep money and resources local, and depend on relationships and faceto-face interactions. Because the Conservation Discourse operates on a large scale, it has a difficult time incorporating regional needs and the largely unquantifiable value of social capital into its structures. The result in Point Reyes is the potential for the gradual destruction of the area's capacity to support agricultural infrastructure and community. The ranchers who lease their land from the National Seashore are in aa particularly difficult situation because they rely on the social capital and infrastructure that the local community supports, but they also rely on the NPS to continue their leases. For this reason, the ranching community has been conspicuously silent in the Drake's Bay Oyster conflict. If indeed the Park intends to eliminate agriculture from the National Seashore, the ranchers could lose everything, so they avoid conflict at all costs.

The debate between use and preservation is deeply ideological. Repeatedly, people trace the root of the conflict back to a kind of 'wilderness zealotry' within the NPS and environmental organizations (Alan Goldstein, Nathan Bird, personal communications). This zealotry is perceived to be almost religious in character, and justifies any means necessary to achieve Wilderness designation, or remove private business. It ignores the positive or neutral environmental effects that pre-existing land uses have, and vilifies them if they are not willing to comply with the Park Service's environmental regulations. To pro-Oyster Farm people, this is infuriating and victimizing, and most likely makes people feel powerless to stop the force of the zealotry within a powerful governmental organization.

In some parts of the United States, agriculture has depleted resources and endangered species (Reich 2001), but on Point Reyes, ranchers and others truly believe that they are positively contributing to maintaining biodiversity and producing food in the most environmentally friendly way possible (Bill Rivers, personal communication). While the Conservation Discourse sees Wilderness and private business as incompatible, the Local Discourse values farmers as stewards of the land and necessary parts of the working landscape. The discrepancy between the Local and Conservation discourses is fundamentally about land use, and the correct way to take care of a valued place. To opponents of the Marine Wilderness Area, the idea of human exclusion for Wilderness is akin to turning dynamic, usable land into a static museum display. 
Wilderness in the Local Discourse seems absurd as a concept because of the long history of human use in the area, and is especially ridiculous and offensive when it comes at the expense of valued community members. The Drake's Bay Oyster Farm conflict got heated and personal partly because people perceived the proceedings as an attack on a well-loved family in the community. Nathan Bird expressed this sentiment well:

And to me the whole idea of Drake's Bay being regarded as wilderness is patently ridiculous. But anyway, to them it isn't. And on the other side you have without question the most exemplary agricultural family in West Marin. I mean the Bishops have been here for generations. They've always been exemplary stewards; they were the first to go totally organic with their pasture and their herd. Everything they do is organic...They are just exemplary in every respect... So the people who love the Bishops saw that as a personal attack on really, really good people. So that complicated and exacerbated the friction. (Nathan Bird, personal communication)

Within the community, the conflict was waged on a personal, local level, which somewhat ironically dissolved many friendships and community connections. Although the roots of the Local Discourse lie in resistance to the erosion of local livelihoods, the Drake's Bay Oyster Farm conflict ruptured the community in a way that may be irreparable. This is possibly due to the fundamental incompatibility of the two dominant discourse frameworks, paired with the community's tendency to get inflamed and personally threatened by the proposition of change.

\section{Local discourse versus conservation discourse in United States parks}

Point Reyes National Seashore is a relatively small Park, and the Drake's Bay Oyster Farm conflict has played out on a relatively small scale, but it is unfortunately one of a number of similar conflicts in the United States. Point Reyes is not the only place where there has been conflict between NPS and pre-existing land uses, difficulties with the concept of wilderness, and reported evidence of fraud and corruption in the NPS. Disgruntled community members in other parks echo many of our informants' feelings about the NPS. One notable example is Channel Islands National Park off the coast of southern California, which is comprised of eight islands, the largest of which are Santa Rosa, Santa Cruz, and Anacapa Islands. Dr. Alan Goldstein believes the fate of ranchers on Santa Rosa Island may foreshadow the future of ranching on Point Reyes.

The Vail and Vickers families had been ranching for several generations on Santa Rosa Island, running over 6,000 head of cattle and maintaining a population of thousands of deer and elk for hunting. They were apparently good stewards by many peoples' assessments and did not overgraze (Barlow 2011). In 1987 the NPS purchased the island, but agreed to give the Vails and the Vickers a twenty-five year transition period to conclude their ranching and hunting operations (Frisch and Wakelee 2011). Subsequently, however, NPS scientists began to believe that ranching and hunting operations were having various deleterious environmental impacts, including harming several threatened species. The Park Service then placed restrictions on the Vail's land use to protect habitat. Channel Islands National Park's former supervisor believes however that "there was no data to show that these impacts (on threatened species) were occurring" and that the NPS intended to drive the ranchers off the island prematurely by imposing strict regulations (Setnicka 2006). In 2011, the Vails and Vickers were forced to close the ranch, cease hunting, and move off the island because it was impossible to stay in business with the NPS's and US Department of Fish and Wildlife's environmental regulations (Barlow 2011). The removal of ranching in Channel Islands National Park does not necessarily indicate the that Park Service was wrong to impose stricter environmental regulations, or that the Vails and Vickers were wrong to feel betrayed and manipulated by the Park Service; rather it demonstrates the difficulties that arise when two very different ways of reasoning and valuing land and environment come into conflict. 
Whenever a National Park is designated, it either occupies a space with no pre-existing permanent land use, it attempts to define its boundaries based on pre-existing land use to exclude as much pre-occupied land as possible, or it arbitrarily creates boundaries that ignore needs of pre-existing residents (Dilsaver and Wykoff 2005; Webb 1987). In most modern parks agriculture, logging, or mining preceded the designation of park boundaries (Dilsaver and Wykoff 2005; Lockhart 2006; Reich 2001). PRNS and Channel Islands National Park are two parks that demonstrate the difficulties that arise when the NPS attempts to interact with pre-existing landholders, and conflicting economic and ideological rationalities come into play. In Shenandoah National Park, the Blue Ridge Mountains were heavily mined and logged previous to the creation of the National Park. When the park was designated in 1928, local landholders were forced to sell their land to the government and move elsewhere, but in subsequent years, Shenandoah National Park has created a deceptive narrative deemphasizing humans' role in the creation of the landscape, and obscuring the rich cultural history of the area (Reich 2001). To create the Mojave National Preserve, the NPS purchased over 84,000 acres from the state of California, and imposed strict regulations on ranchers with pre-existing grazing permits on the land to encourage them to move grazing operations elsewhere (Dilsaver and Wykoff 2005). In Point Reyes, agriculture is currently an accepted section of the National Seashore, but it is unclear whether the NPS will decide that agriculture is environmentally damaging and remove it from within park boundaries, as it has done with a number of other parks.

While value conflicts are perhaps inevitable in land conservation, reports of corruption and a problematic culture in the NPS complicate Park-landholder relationships and expose stakeholders' unequal power. In his analogous account of NPS corruption in the persecution of the trader at the Hubbell Trading Post (in Arizona), ex-Park Service employee Paul Berkowitz describes an agency culture that champions NPS loyalty above all else. He argues that this may result in corruption that is rarely uncovered, and unsavory activities that are condoned and even rewarded by higher-ups. He explains:

One simply does not challenge the NPS culture or its leadership or mention problems and make complaints outside of the internal agency structure. The image of the agency is paramount, and that's one reason why it so successfully garners public and political support...it's not all that surprising that the NPS has evolved into a very insulated, provincial, and sometimes cult-like institution. (Berkowitz 2011: 62)

Berkowitz's assertions echo some of our informants' concerns about the insular, opaque nature of the Park Service in Point Reyes, and may help to explain the Park's difficulty with being open and honest about possible scientific misconduct in Drake's Bay Oyster Farm studies. In a letter to Mark Bishop of Drake's Bay Oyster Farm, former superintendent Setnicka of Channel Islands Nation Park wrote that he supported Bishop in his efforts to preserve the oyster farm, and recognized the enormity of the power he was up against. He added: "One enormous success you have had is the finding by the Dept of Interior about what the NPS routinely does- that is to manipulate and spin information to support the NPS's own purposes against their opponents" (Setnicka 2006:1). This institutional culture described by Berkowitz, Setnika, and some of our informants helps to explain the strength and power of the self-reinforcing conservation discourse the NPS has created, and the difficulties that arise when a non-local tries to question the discourse.

Cooperation between Parks and private in-holders and traditional land users is not impossible. The NPS has, to its credit, identified the need to partner with local groups and residents to manage resources or concessions in some parks, and consequently it has been working on a series of 'partnership parks' where "rather than having the community on the outside looking in, the community becomes central to management decisions" (Hamin 2001: 125). These parks, such as The Tallgrass Prairie National Reserve, the Mojave National Reserve, and the Mississippi National River and Recreation Area, seem similar to PRNS in that they are places with important ecological resources and a rich history of human use. These 'partnership parks' represent a hopeful movement towards place-sensitivity in the National Park system, and the needs of local people. They suggest the possibility of collaboration between local land use and conservation in a way that is fair and mutually beneficial to all stakeholders. This will require NPS employees who are comfortable with 
sharing power and communicating openly, and depends on the pre-existing goodwill of the local people, both of which are difficult to find in many parks (Hamin 2001; Stern 2008; see also McCoy and Haenn 2013).

\section{Global challenges}

Globally, the number of parks and protected areas are increasing as biodiversity conservation gains importance in many countries (West et al. 2006). In all countries, protected areas are material manifestations of narratives about nature and people, and almost always engage a diverse variety of stakeholders, including governments, NGOs, local people, and scientists, as the Drake's Bay Oyster conflict did. In this way, protected areas are common arenas for social interaction, conflict, and change (McCoy and Haenn 2013). They incite new power relations and invoke state authority, and in developing countries, often bring indigenous and local peoples' rights into question as people are removed from within park boundaries (Adams and Hutton 2007; Blaikie 1995; West et al. 2006). Almost invariably, whenever a PA is created, the resulting land use, resource use, and the social structure of local people changes, and this can be fodder for conflict and disenfranchisement.

There is a large body of work in anthropology, political ecology, and geography that focuses on the interplay between local, often indigenous needs, and conservation goals in parks worldwide (West et al. 2006). Some openly question the possibility for conservation and human land use compatibility given the drastically different pathways that define each (Adams and Hutton 2007). The aspects of conflict and the divergent discourses identified in Point Reyes National Seashore are not limited to this case study, or even to parks in the United States. But this study seeks to enrich the literature and debate over political ecology and parks in developed countries. Loss of social capital, struggles with tourism, and amplification of social struggles are common to many communities in and around parks (Adams and Hutton 2007; Robbins 2012; West et al. 2006). While the NPS is unique to the United States, an authoritative federal power is consistently present in the creation and enforcement of park rules and boundaries in most countries, as it is in the US. As Adams and Hutton (2007:158) point out, "States claim legitimate power to enforce socially desirable outcomes, and on this ground, the protection of nature as state policy has often involved coercion, particularly where it has involved the displacement of human communities from PAs." The power for coercion, however, extends beyond the government to NGOs and scientists. Inequality of stakeholder power is a crucial consideration in any PA, because almost always the local or indigenous people have far less agency and political power than the agencies and organizations that get to make final land use decisions (Heatherington 2010). Whether it is the displacement of indigenous people from homelands and sacred places or the coercion of ranchers in US parks, or in this case the exclusion of a long-standing oyster farm, there are powerful and less powerful discourses, yet each are deserving of consideration and fair scrutiny.

\section{Conclusion}

This article adds to the growing body of literature on the relationships between federally designated protected areas and local communities in the United States. We have also emphasized, in particular, the changing process of conservation discourse that actively continues to exclude human uses within park boundaries. Protected areas and affected local users thus respond dynamically to shifting agency demands and enclosure acts, and the PRNS is one of the most visible examples of this process. Particular agency power creates a prominent and authoritative form of discourse for the NPS, and these narratives and concepts then come to be accepted as truth. In the Point Reyes case, the NPS used its powerful agency and its local strategic conservation allies to deploy a discourse of nature conservation which rarely accommodates existing human agency or presence based on a historical social construction of a once-pristine nature.

This is not meant to be a condemnation of national parks or the NPS. These parks and the agency itself provide opportunities for millions of people to visit outdoor places and learn something about the natural world, while denying land for commercial development. The conservation discourse used by the NPS, however, is often so authoritative, operating behind closed doors, that it drowns out the protests of local people who see human-free land conservation as problematic (see also McCoy and Haenn 2013). A political ecology of NPS-local land use conflict reveals that there are conflicting discourses at play in Point Reyes 
National Seashore and in other parks throughout the country, and local land users sometimes feel unheard because of the NPS's ultimate authority over land use in National Parks, Preserves, and Seashores.

Drake's Bay Oyster Farm continued to operate until the end of 2015, and they have now been vacated from their forty-year home. The Park Service has already put over US\$200,000 into removing all traces of the oyster farm so Drake's Estero can become the west coast's first Marine Wilderness Area, to the delight of some and the chagrin of others (Clark 2016). Since this article was written in 2014, the discourses discussed above continue to be engaged in PRNS although the stakeholders employing each discourse shift, sometimes in surprising ways. Since the Drake's Bay conflict, the NPS has been working on the construction of a 'Ranch Comprehensive Management Plan', appearing to acknowledge the ranches' importance in the park and making plans for their continued existence. Three environmental non-profit organizations, however, have filed a federal suit in an effort to require the NPS to conduct an Environmental Impact Assessment of the ranches. Although many, including the NPS, have come to see ranches as a valuable part of both the cultural and ecological value of the park, these three environmental organizations feel that cattle use space and resources that should be available to the population of Tule elk in the park, especially in the drought conditions that California has been experiencing. They fear that the 'Ranch Comprehensive Management Plan' will institutionalize and make permanent the ranches in PRNS without fully assessing their environmental impact (Greenaway 2016). Interestingly, the Point Reyes Seashore Ranchers' Association has requested to be entered as co-defendants in this lawsuit, demonstrating solidarity between ranchers and the NPS where there was sometimes animosity during the Drake's Bay conflict (Kimmey 2016). Tracking these shifting, strategic alliances on which uses will be valued, and at what point in time, will be vital to understanding the future role of ranching in the region. The case of Point Reyes National Seashore has shown that Conservation Discourses and Local Discourses are engaged repeatedly in conflicts in PRNS. The net result is similar to conflicts where resource use differs from large-scale narratives of conservation and preservation (McCoy and Haenn 2015). The PRNS example, however, is useful for illustrating and explaining the changing process of discourses and power of conservation agencies over time.

\section{References}

Adams, W and J. Hutton. 2007. People, parks, and poverty: political ecology and biodiversity conservation. Conservation and Society 5(2): 147- 183.

Barlow, Z. 2011. End of an era on Santa Rosa Island. Ventura County Star. Nov. 12.

Berkowitz, P. 2011. The case of the Indian trader: Billy Malone and the National Park Service investigation at Hubbell Trading Post. Albuquerque: University of New Mexico Press.

Blaikie, P.M. 1995. Changing environments or changing views? Geography 8(3): 203-214.

Burnham, P. 2000. Indian country, God's country. Washington, D.C.: Island Press.

Brown, K. 1998. The political ecology of biodiversity, conservation and development in Nepal's Terai: confused meanings, means and ends. Ecological Economics 24(1): 73-87.

Charnley S., T. Sheridan, and G. Nabhan (eds.). 2014. Stitching the West back together. Chicago, IL: University of Chicago Press.

Clark, L. 2016. 'Oyster Wars', what really happened to Drakes Bay farm. The Press Democrat. Sept. 16. http://www.pressdemocrat.com/lifestyle/4456375-181/oyster-war-what-really-happened?artslide $=0$

Dilsaver, L. and W. Wyckoff. 2005. The political geography of National Parks. Pacific Historical Review 74(2): 237- 226.

Escobar, A. 1999. After nature: steps to an antiessentialist political ecology. Current Anthropology 40(1): 130.

Escobar, A. 1996. Elements for a Post-Structuralist Political Ecology. Futures 28(4): 325-343.

Evans, J. 2008. Natural history of the Point Reyes Peninsula. Berkeley, CA: University of California Press.

Foucault, M. 1982. The subject and power. Critical Inquiry 8(4): 777-795.

Forsyth, T.J. 2013. Critical political ecology: the politics of environmental science. London, UK: Routledge. 
Frisch, S. and D. Wakelee. 2011. Resisting the pressures of the present: Channel Islands National Park as a case study in public policy making. The Journal of Policy History 23(2): 230-250.

Goodman, C. 2013. Request for investigation of scientific misconduct. Unpublished manuscript.

Greenaway, T. 2016. Ranching in Point Reyes National Seashore called into question. Edible Marin and Wine Country. http://ediblemarinandwinecountry.ediblefeast.com/food-thought/ranching-point-reyesnational-seashore-called-question.

Hamin, E. 2001. The US National Park Service's partnership parks: collaborative responses to middle landscapes. Land Use Policy 18: 123-135.

Heatherington, T. 2010. Wild Sardinia: indigeneity and the global dreamtimes of environmentalism. Seattle, WA: University of Washington Press.

Hull, R.B., D.P. Robertson, and A. Kendra. 2001. Public understandings of nature: a case study of local knowledge about "natural" forest conditions. Society and Natural Resources 14: 325-340.

International Union for the Conservation of Nature. 2014. Priority area 3: protected areas...achieving quality. Accessed 4/26/15. http://www.iucn.org/about/work/programmes/gpap home/gpap quality/

Jamal, T. and M. Eyre. 2003. Legitimation struggles in National Park spaces: The Banff Bow Valley round table. Journal of Environmental Planning and Management 46(3): 417- 441.

Kimmey, S. 2016. Splintered ranchers group reborn in wake of seashore lawsuit. Point Reyes Light. http://www.ptreyeslight.com/article/splintered-ranchers-group-was-reborn-wake-seashore-lawsuit

Kull, C. 2002. Madagascar aflame: landscape burning as a peasant protest, resistance, or a resource management tool? Political Geography 21(7): 927-953.

Langston, N. and W. Cronon. 2003. Where land and water meet: a western landscape transformed. Seattle, WA: University of Washington Press.

Little, P. 1999. Environment and environmentalisms in anthropological research: facing a new millennium. Annual Review of Anthropology 28: 253-284.

McCoy, R and N. Haenn. 2013. "Gentlemen-type rules" and "back room deals" in public participation: natural resource management and a fractured state in North Carolina. Journal of Political Ecology 20: 444-459.

Meyer, G. 2011. Oyster culture. Petaluma CA: Cameron and Company.

Moore, DS. 1993. Contesting terrain in Zimbabwe's eastern highlands: political ecology, ethnography, and peasant resource struggles. Economic Geography. 69(4):

Moran, E. 1990. Ecosystem ecology in biology and anthropology: a critical assessment in Moran, E. (ed.) The ecosystem approach in anthropology. Ann Arbor: University of Michigan Press. Pp 1-30.

Natter, W. and W. Zierhofer. 2002. Political ecology, territoriality and scale. Geojournal 58 (4): 225-232.

Neuman, R.P. 1992. Political ecology of wildlife conservation in the Mt. Meru area of northeast Tanzania. Land Degradation and Development 3(2): 85-98.

Phillips, A. 1999. Working landscapes as protected areas. In Dudley, N. and S. Stolton (eds.) Partnerships for protection: new strategies for planning and management for protected areas. London: Earthscan. Pp. 205-214.

Proctor, J. 1998. The social construction of nature: relativist accusations, pragmatist and critical realist responses. Annals of the Association of American Geographers 88(3): 352-376.

Sadin, P. 2007. Managing a land in motion: an administrative history of the Point Reyes National Seashore. Prepared for National Park Service, Point Reyes National Seashore. http://www.nps.gov/history/history/online_books/pore/admin.pdf

Salazar, K. 2012. Decision memorandum: Point Reyes National Seashore- Drakes Bay Oyster Company. National Park Service. https://www.nps.gov/pore/getinvolved/upload/PORE_Nov-29-2012-Secretarys-Memo.pdf 
Setnicka, T. 2006. A brief history: Channel Islands National Park, the Vail Family, and Santa Rosa Island. Santa Barbara News. 10/8/06

Schiffrin, D. 1994. Approaches to discourse. Cambridge, MA: Blackwell.

Schneck, S. 1987. Michel Foucault on power/discourse, theory, and practice. Human Studies 10(1): 15-33.

Schroeder, R.A. 2005. Debating the place of political ecology in the First World. Environment and Planning A 37(6): 1045-1048.

Stern, M.J. 2008. The power of trust: toward a theory of local opposition to neighboring protected areas. Society and Natural Resources 21(8): 59-875. Researchgate

Reich, J. 2001. Re-creating the wilderness: shaping narratives and landscapes in Shenandoah National Park. Environmental History. 6(1): 95-117.

Robbins, P. 2012. Political ecology: a critical introduction. Oxford: Wiley-Blackwell.

Vaccaro, I. and O. Beltran. 2009. Livestock versus "wild beasts": contradictions in the patrimonialization of the Pyrenees. Geographical Review 99(4): 499-516. Researchgate

Walker, P. 2003. Reconsidering 'regional' political ecologies: toward a political ecology of the rural American West. Progress in Human Geography 27(1): 7-24.

Watt, L.A. 2013. United States Court of Appeals for the Ninth Circuit: Kevin Lunny and Drakes Bay Oyster Company. San Francisco: United Stated Court of Appeals.

Weaver, B.J. 1996. What to do with the mountain people? The darker side of the successful campaign to establish the Great Smoky Mountains National Park. In Cantrill, J.G. and C.L. Oravec (eds.) The symbolic earth. Lexington, KY: University Press of Kentucky. Pp. 151-175.

Webb, M. 1987. Cultural landscapes in the National Park Service. The Public Historian 9(2): 77-89.

West, P., J. Igoe, and D. Brockington. 2006. Parks and people: the social impact of protected areas. Annual Review of Anthropology 35: 251- 277.

West, P. 2006. Conservation is our government now: the politics of ecology in Papua New Guinea. Durham, NC: Duke University Press.

Wetherell, M., S. Taylor and S. Yates, (eds.). 2001. Discourse theory and practice: a reader. London, UK: Sage.

Wilderness Act. 1964. Public Law 88-577 (16 U.S. C. 1131-1136), 88th Congress, Second Session. http://www.wilderness.net/NWPS/legisact?print=yes

Wilson, R. 2014. America's public lands: from Yellowstone to Smokey Bear and beyond. Lanham, MD: Rowman and Littlefield. 